\title{
全球気候モデル出カのバイアス補正手法の違い による水文解析への影響 \\ EFFECTS OF DIFFERENCES IN BIAS CORRECTION METHODS TO GENERAL CIRCULATION MODEL OUTPUT ON HYDROLOGICAL ANALYSIS
}

\author{
眞㠃良光 ${ }^{1} \cdot$ 花崎直太 $^{2} \cdot$ 高橋潔 $^{3} \cdot$ 肱岡靖明 4 \\ Yoshimitsu MASAKI, Naota HANASAKI, Kiyoshi TAKAHASHI and Yasuaki HIJIOKA

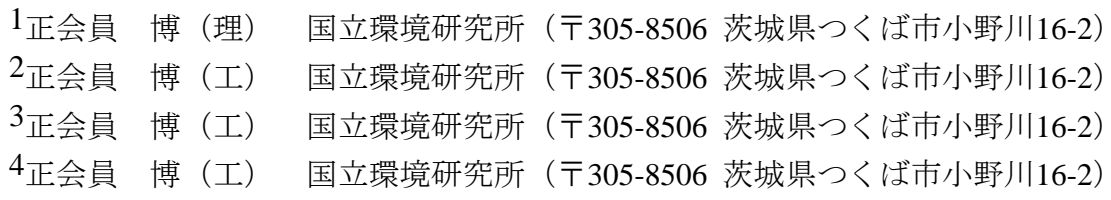

\begin{abstract}
We have compared differences in hydrological simulation results when two different types of bias correction methodologies were applied to general circulation model output. The methodologies are: (1) a shifting-and-scaling method and (2) a quantile mapping method. Similar seasonal variations of 30-yearmean river discharge were obtained for the both bias correction methods. However, for the maximum monthly discharge in 30 years, the shifting-and-scaling method tends to produce larger values than the quantile mapping method. This feature attributes characteristics on multiplication factors for producing future precipitation data: The maximum end of a precipitation range is selectively affected by the factor. This feature might overestimate future risks of flooding. Since future projection of the river discharge directly links to evaluation of risks accompanied with future climate changes, we should pay attention to bias correction methods when we interpret hydrological simulation results.
\end{abstract}

Key Words : River discharge, inundation probability, bias correction, climatic change, hydrological simulation

\section{1.はじめに}

温暖化に伴う水文量の将来予測，特に将来の河川流量 の把握は, 洪水や干ばつ等の社会的リスク評価にとって 不可欠である. 将来気候予測には全球気候モデル

（GCM）が用いられているが，各GCMは固有のバイア スを含むため, それらを適切に補正する必要がある。 バ イアス補正手法は各種提案されてきたが，主に(1)補正量 の加乗演算により気候要素の平均值を合わせる手法と, (2)気候要素の度数分布を合わせる手法の，2種類が多く 用いられている. (1)は, 度数分布が現在気候の相似形に しか成り得ないものの, 簡単な算術演算で計算負荷が小 さいことから，多くのモデルで採用されている，一方， (2)は度数分布の補正が可能であるものの, 大きな計算負 荷や作業労力を強いられるため, それらを負担できる研 究組織に使用が限定される傾向があった. しかし，実
際に発現し得る気象事象に即した将来予測研究への期待 から，近年，(2)の利用が急速に進みつつある.

これらの気象データを入力值としたモデル計算は世界 各国で行われ，将来の気候変動による影響予測は大きく 進展したが，それに伴い，バイアス補正に対寸る気候変 動予測結果の感度についても研究者の関心が集まってい る. 水文解析においても, GCMの気象要素に対するバ イアス補正が，将来の水文予測結果に与える影響につい て指摘されており1), バイアス補正に対する感度の検証 が進みつつある。

そこで，今回，2つの異なる手法でバイアス補正され た気候データを入力したとき, それらが水文解析結果に 与える影響の評価を目的として, 解析を行なった. 本報 告では, (1)(2)両手法を用いたときに得られる流出量や 河川流量の結果を比較して，その影響を調査した。

\section{2. 手法}


GCMとしてMIROC-ESM-CHEMを用い，これから得 られた気象要素を $0.5^{\circ} \times 0.5^{\circ}$ の空間分解能に補間して使用 した. 全球陸域を解析対象とし, 将来予測対象期間は 2011〜2040年，および2041〜2070年の各30年間である. 将来の温室効果ガス排出濃度シナリオとして, 代表的濃 度シナリオ $(\mathrm{RCP}){ }^{2)}$ の2.6および8.5を使用した. 水文モ デルはH083)を使用し, 日別值の気象要素を入力して, 水文過程の積分計算の時間間隔を1日として計算した. バイアス補正の水文計算結果への影響に主眼を置いたた め, ダム操作や灌泊等の人為的水操作は扱わない. 本解 析では，流出量および河川流量に着目した．河川流量に ついては，世界43河川（図-1）の主要流量観測地点にお ける日別流量を解析した. なお，この 43 河川は， $2 \times 10^{5}$ $\mathrm{km}^{2}$ 以上の集水面積を持ち，特定の大陸や気候区分に偏 在しないように選定されている.

水文モデルの陸面過程計算のために入力する気象デー 夕は，2種類のバイアス補正手法に対応して2種類のデー タセットを用意した．先述の(1)は，シフティング\&ス ケーリングと総称される（以下，SS手法と称する）.

SS手法では，GCMの30年間平年值をもとに，気候変化 による変化量 (気温) あるいは変化率 (降水量・下向き 長波放射）を月別に求めた後で，観測べースの全球グ リッド気象データであるWATCH気象データ4)の1971〜 2000年日別気象要素に変化量を加算あるいは変化率を乗 算することで, 将来の日別気象要素を作成した. 一方, (2)では，Pianiらのアルゴリズム5),6)用いた（以下， Piani手法）。本解析では，ISI-MIPプロジェクトが作成 し，配布・提供しているデータセットをそのまま使用し た（詳細は同プロジェクト文書》を参照）。これは, 1960 1999年のWATCH気象データとGCMの気象データ
から, 気象要素日別值の累積度数分布をそれぞれ求め, WATCH気象データの分布に合うように変換する関数を 決める手法である. 変換関数は月ごとに決めるものの, 月界における不連続性を避けるため, 変換関数のパラ メータを補間し，日別気象要素に適用する，バイアス補 正は，気温・降水量をはじめとする全気象要素入力値に 適用される.

結果の解析手順として，まず平年值・全球規模での入 力気象要素や流出量について, 次に平年値での河川流量 について，それぞれ両バイアス補正手法を用いたときに 得られた結果の相違を調べる。もし，これらに顕著な相 違が生じた場合は，その原因を調べる。

\section{3. 結果}

\section{（1）平年値の全体的傾向}

まず，現在（1971～2000年）に対するRCP2.6，2011〜 2040年の年平均気温・降水量の変化傾向（ここでは， Piani手法による結果）を図-2に示す，気温については, 北半球高緯度の陸域で平均気温の上昇が大きい。これは, 冬季における気温上昇を反映している。.また，降水量も， 北半球高緯度て増加傾向を示寸. SS手法についてもほぼ 同様の結果が得られており，両手法による結果を比較す るため，基準期間平年值に対する2011 2040年の平均気 温の変化量および降水量の変化率について, 両バイアス 補正手法間での差分をとった（図-3）。その結果，気温 については $1^{\circ} \mathrm{C}$ 未満であった. 降水量については, 少雨 地域を中心に，20\%以上の相違を生じた地域がある.ブ ラジル中部は，多雨地域であるものの，10\%程度の相違 を生じた，それ以外の地域では，比較的軽微である。

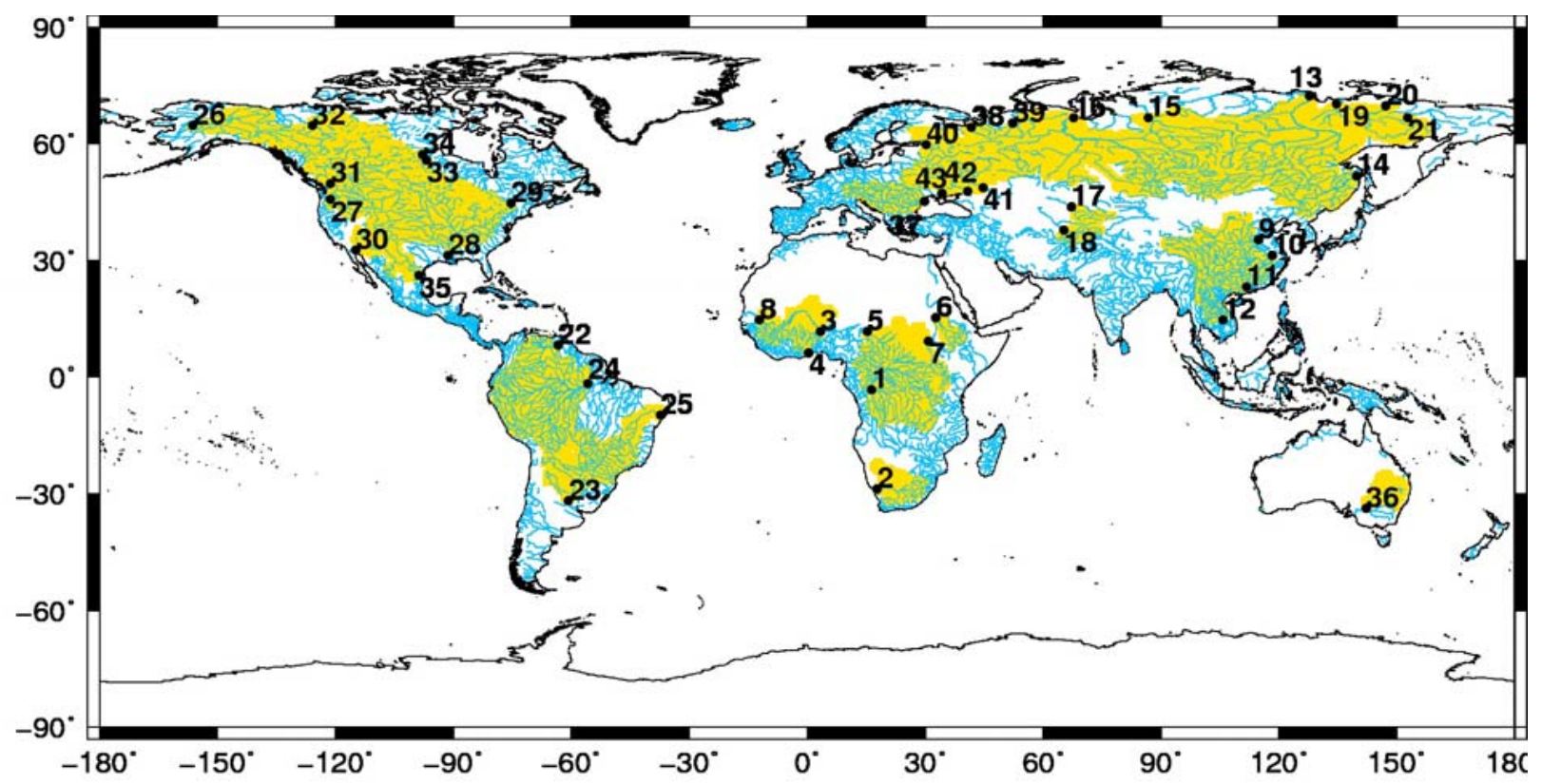

図-1 解析対象とした43河川と流量解析地点（黒丸印），黄色の領域は，流量解析地点の上流域を示す． 

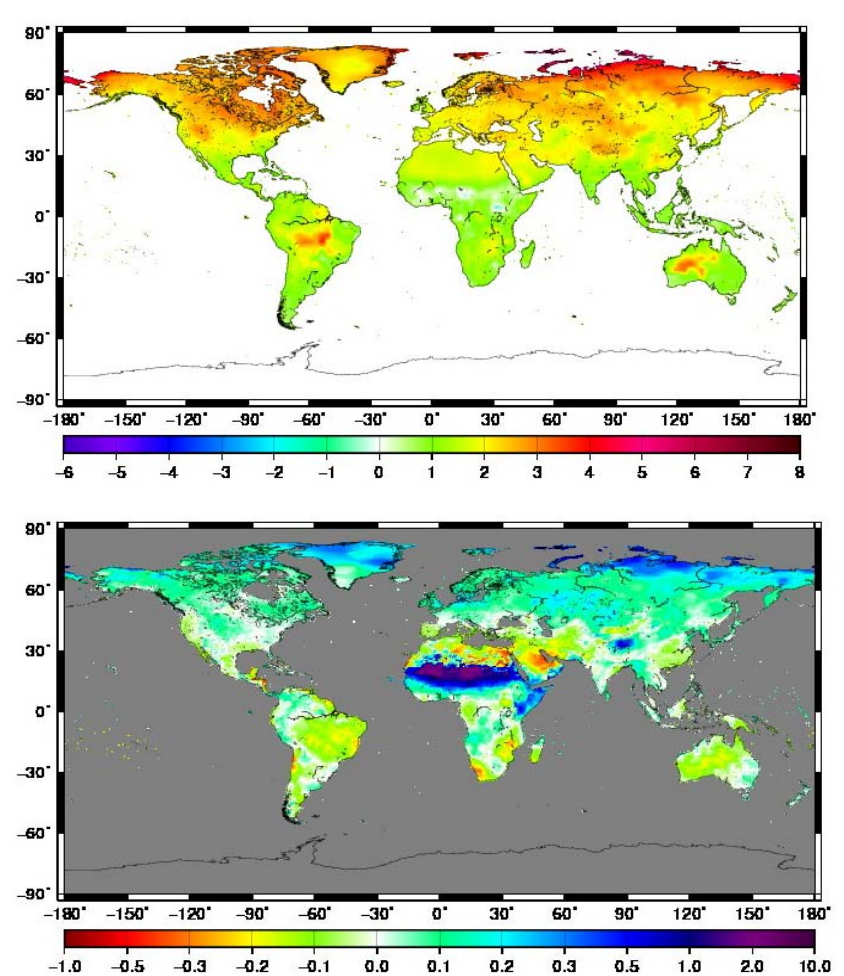

図-2 1971-2000年平均のWATCHデータに対するRCP2. 6, 20112040 年平均の気温の変化量 $\left({ }^{\circ} \mathrm{C}\right)$ （上）と降水量の変化 率（下）
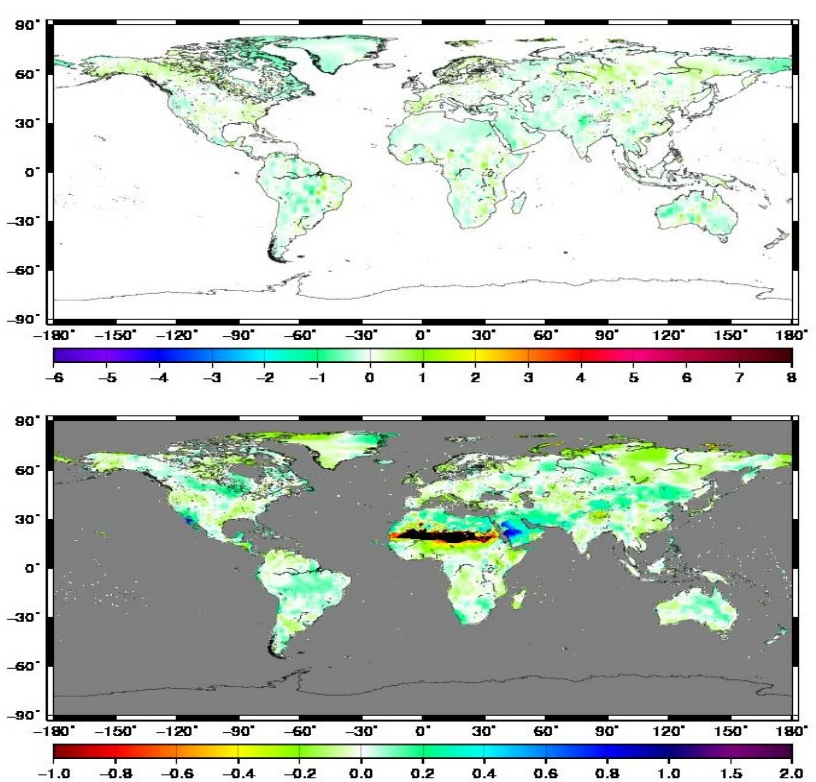

図-3 SS手法とPiani手法における気候変化傾向の違い. それぞ れの基準期間（すなわち現在気候值）に対する RCP2. 6, 2011-2040年の気温の変化量 $\left({ }^{\circ} \mathrm{C}\right) \quad$ （上）および 降水量の変化率（下）について, SS手法適用結果から Piani手法適用結果を差し引いたもの.

次に, RCP2.6，2011～2040年における2種類のバイア ス補正手法に基づくデータセットを用いて解析された平 均流出量を図-4に示す。全体的な傾向は同一であるが,
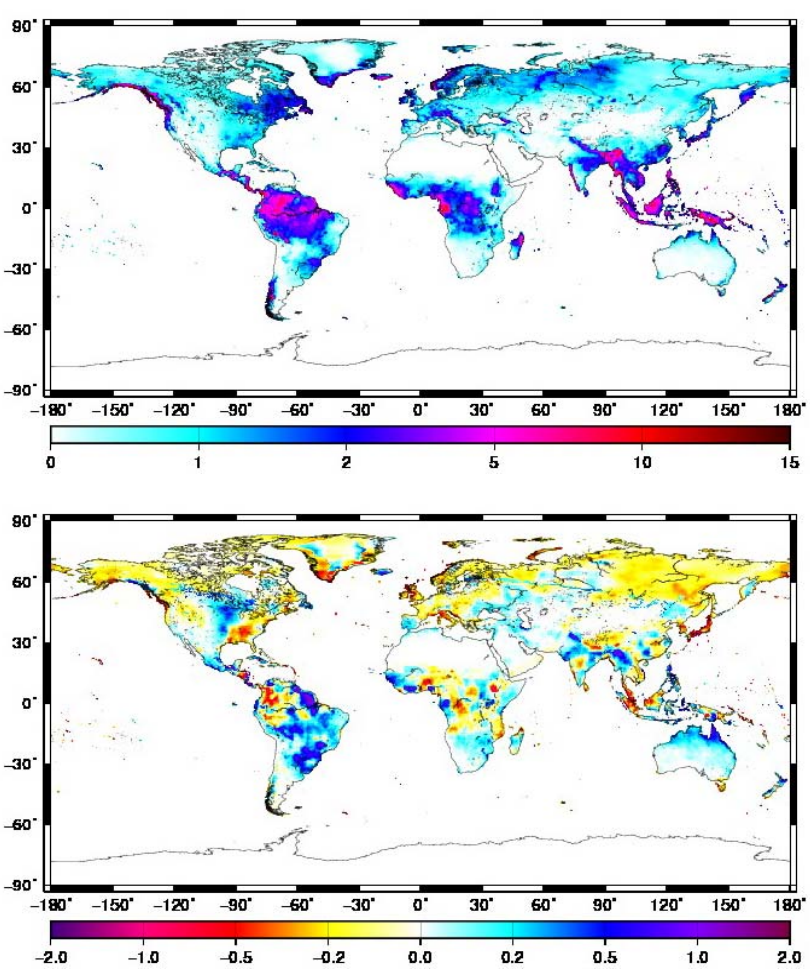

図-4 RCP2. 6, 2011-2040年におけるSS手法（上）による平均流 出量 $(\mathrm{mm} / \mathrm{d})$ と, 両手法 (SS-Piani) の平均流出量の差分 $(\mathrm{mm} / \mathrm{d})$ (下) .

両者の差分をとると，陸域の大部分で $0.2 \mathrm{~mm} / \mathrm{d}$ 以下，多 雨の地域でも $0.5 \mathrm{~mm} / \mathrm{d}$ 程度の範囲内に収まっている．北 半球高緯度ではPiani手法の流出量の方が，南半球ではSS 手法の流出量の方が，それぞれわずかに大きい傾向が見 られる.しかし，この傾向は，季節によっても異なるた め，両手法間で著しい地域的特性の違いを生んでいると は断定できない.

\section{（2）上流域平均水文諸要素の平年值}

河川流量の変動は，その上流の流出量の変動を反映し たものであり，その流出量は，降水量と蒸発散量に依存 する. そのため, 降水量, 蒸発散量, 流出量について, 観測地点上流域で平均化した值（面積による重み付け平 均）を求め，バイアス補正手法間で比較した。 なお，厳 密には観測地点に流下寸るまでの時間ラグを考慮した議 論が必要だが，本解析では，月別の時間分解能で議論す ることを勘案し，流下に要する時間ラグを無視する。

その結果，これらの要素についても，月別平年值では， バイアス補正手法間に大きな違いは見られなかった。ま た，ほかのRCP，将来予測期間についても同様，両手法 間に大きな違いは見られなかった (図表未掲載)。 


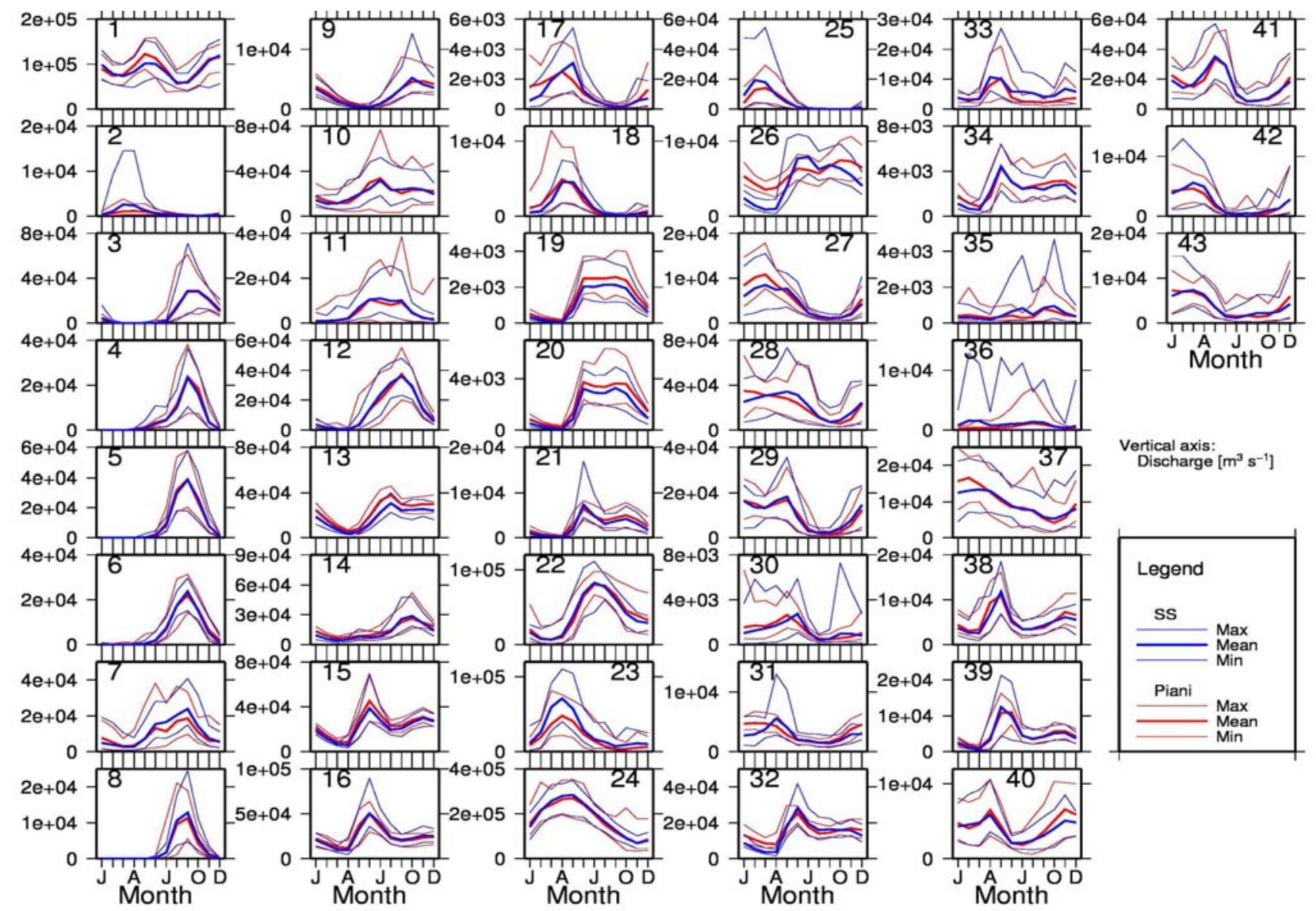

図-5 RCP2.6における月別平均河川流量の季節変動（ $\left.\mathrm{m}^{3} / \mathrm{s}\right)$. 青線はSS手法, 赤線はPiani手法によるバイアス補正結果であり, そ れぞれ2011-2040年の30箇年における平均（太線）と最大・最小値（細線）をプロットした．各パネルの番号は，図-1の流量 解析地点の番号を示す.

\section{（3）河川流量}

図-5は，43河川の流量解析地点における月別平均河川 流量について，バイアス補正手法ごとに，30箇年におけ る同月の平均值 (つまり平年值) および最大・最小值を 示したものである．平年値の季節変動を見る限り，一部 の地点（地点\#26，32等）を除き，バイアス補正手法間 の結果に顕著な違いや系統的な違いを見出すことはでき なかった。

しかし，図-5において30箇年の最大值を見ると，Piani 手法に比べ，SS手法の方が大きく評価された地点が多い. この現象は，季節別では豊流期に見られや寸い. なお， この現象が見られた地点は，特定の地理的分布をするわ けではなかった，なお，30箇年の最小值についても，渴 水期を中心に同様の調查をしたが，バイアス補正手法間 に顕著な差異はみられなかった。

ほかのRCP, 将来予測期間については, 補正值が異な るため, 多少の差異はあるものの，同様の傾向が得られ た.

\section{（4）上流域平均月別降水量の30箇年の順位分布}

前項の河川流量の30箇年最大值に見られた較差の原因 を調べるためには，平年值ベースではなく，順位ベース で比較することが必要となる，そこで，月別の上流域平
均降水量について，2種類のバイアス補正手法それぞれ に対して同月のデータ30箇年分を昇順に並べ替えた上で, その散布図を作成した。 これにより，両手法間で，月別 降水量の順位分布や降水量頻度分布の違いを検出できる. ここでは, 解析対象の43地点のうち, 図-5においてPiani 手法よりSS手法で大きな值を示した8地点（グループA; 地点\#2, 21, 25, 30, 31, 35, 36, 42） と, 対照群として, 逆 に小さい值を示した2地点（グループB; 地点\#11，18）を 選び，その上流域平均月別降水量と，SS手法において適 用した降水量変換係数 $\alpha$ の值を図-6にまとめた.

その結果, 地点によって, SS手法とPiani手法の月別降 水量が一致する1:1ラインから大きく外れ，両バイアス 補正手法間で月別降水量の順位分布に大きな違いがある ことが分かった．また，その違いは，地点のみならず季 節によっても異なる. 特に, ここに例示したグループA の8河川では, 図-5のSS手法で最大月平均流量が大きめ に見積もられた季節を中心に，上流域平均降水量につい てもSS手法で大きめに見積もられる傾向がある.ささら， 順位分布も1:1ラインの傾きより急傾斜を示寸．これは, Piani手法で得られる30箇年の月別降水量のレンジに比べ, SS手法のレンジが大きいことを意味する．また，少ない 月別降水量側（各パネルの左下隅）では1:1ラインに沿 うものの, 降水量が増えるとともに, 上方に屈曲する分 

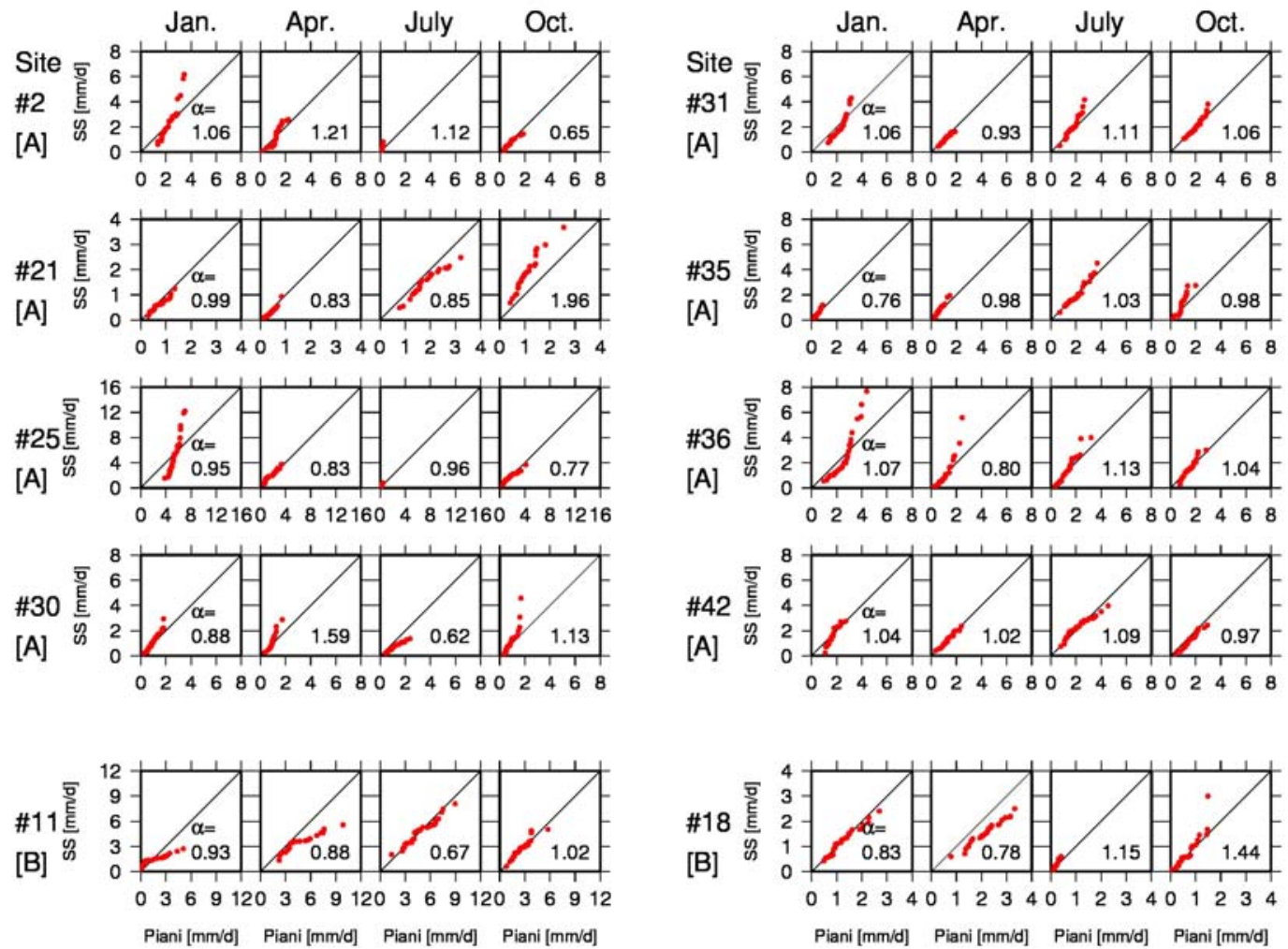

図-6 RCP2. 6，2011-2040年における月別降水量の 2つのバイアス補正手法間の散布図. 図-5において，Piani手法に比べSS手法で 大きな值を示した8地点（グループA）および小さな值を示した2地点（グループB）について取り上げた．降水量は，流量観 測地点より上流の領域での平均値３0年間の同月データについて，各手法の月別値をそれぞれ昇順に並べ替え，横軸にPiani 手法，縱軸にSS手法による月別降水量值（単位 $m / \mathrm{d}$ ）をとってプロットしたもの. $\alpha$ は，SS手法の降水量変換係数を示す.

布形状も見られる.この場合，平年並もしくは少雨年で は，月別降水量に両手法間での較差が見られないものの, 十年に数回の頻度で発生する多雨年においては，その降 水量がSS手法で大きめに見積もられることを意味する.

逆に，グループBの2河川では，SS手法で最大月平均 流量が小さめに見積もられた季節を中心に，1:1ライン より緩い傾斜を示している.

\section{4. 議論}

\section{（1）スケーリングによる降水量バイアス補正手法と極值 への影響}

SS手法による降水量のスケーリング変換は，基淮期間 における降水量データの值を $\alpha$ 倍にする. 降水量は非負 值であるため, 基淮期間の降水量レンジが $[0, P \max ]$ であ る場合，変換後のレンジは $[0, \alpha \operatorname{Pmax}]$ となる。つまり， ある月の変換係数 $\alpha>1$ であれば，バイアス補正後の最 小降水量值は 0 で変わらないものの, 最大值は必ずより 大きな值へと変換される，逆に， $\alpha<1$ であれば，最大 值はより小さな值に変換される。、ずれにおいても，ス ケーリング変換によって, 最大值側にあるデータほど大 きな影響を受ける．結果として，30年間の気象データか
らSS手法により将来気象データを作成する場合，変換前 の降水量データでは, Pmaxの降水量は30年に1度生起す るが，変換後の降水量データでは， $\alpha \operatorname{Pmax} の$ 降水量が 30年に1度, 確実に生起することになる.

このようなスケーリングの変換特性は, 図-5でバイア ス補正手法間の差異として，30箇年の最大月平均流量か らは検出できても, 最小月平均流量からはほとんど検出 できなかったことにも現れていると考えられる.

洪水頻度の将来予測は, 水文解析にとって重要である が，バイアス補正の変換特性から算術上生じる “洪水” を, 将来気候下で実際に起こり得る洪水事象として解析 してしまう危険性を内在している。 その逆に，バイアス 補正の特性次第では，洪水事象を見逃す危険もある。

なお， $\alpha$ 〜であるにもかかわらず，図-6で急傾斜を 示寸いくつかの事例（地点\#2の1月，\#25の1月）も確認 された.これらは，SS手法に比べてPiani手法の30箇年の 降水量レンジが小さくなる特徵がある. 本報告では，こ の原因を明らかにできなかったが，これらの流域は複雑 な地形起伏のある山岳・丘陵地域にあるため, 気象条件 のわずかな違いによる降水特性への影響や，GCMによ る観測降水特性の再現の難しさ等も影響している可能性 がある. 今後の課題としたい.

本研究では, 冒頭でも述べた通り, バイアス補正手法 


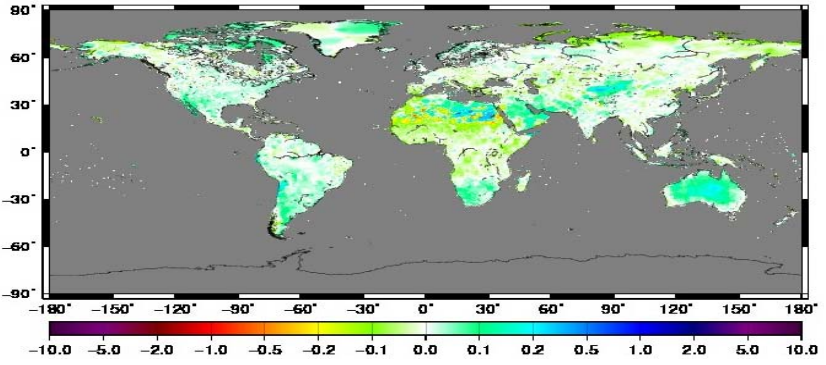

図-7 WATCH年平均降水量について「1971-2000年平年値」から 「1960-1999年平年値」の差を, 後者で規格化した值.

の違いによる水文解析結果一の影響比較を通して，その 危険性の一つを指摘した. しかし，これは両手法間の優 劣を結論づけるものではない．両手法の特性の違いを把 握した上で，水文解析の結果を解釈寸る際，注意するこ とが重要だと考えられる.

\section{（2）バイアス補正基準期間の違いによる影響}

本解析で用いたフォーシングデータとしての気象デー タセットは，同じWATCH気象データに準拠してバイア ス補正を施したものであるが，SS手法では1971-2000年， Piani手法では1960-1999年と異なる年次の平年值を基準 にしている．数十年間という長期間の平年值といえども, 基準期間の平年值自体に較差がある場合，バイアス補正 後の気象データセットにもその影響が及ぶ可能性がある そこで，両基準期間におけるWATCH年平均降水量の差 （降水量の絶対值で規格化）を図-7に示した．乾燥域で は，年間降水量が少ないため，稀有な降雨事象や小さな 降水量值での規格化により不安定的に高值を示すことは あるが，それを除けば，陸域の大部分で5\%程度の相違 にとどまり，バイアス補正基準期間の違いによる影響は, 前項までに結果として示した両バイアス補正間の降水量 較差と比べても軽微であると考えられる.

\section{5. 結論}

GCMによる将来気候変動予測において，よく用いら れる2種類のバイアス補正手法（SS手法，Piani手法）で 生成された 2 種類の気象データを水文モデルに入力し, その結果の比較を通して, バイアス補正手法の水文解析 への影響を検証した。

流出量や河川流量の平年値には，両バイアス手法間の 顕著な相違は見られなかった。しかし，30箇年における 最大月平均流量など，最大側極值において，SS手法で大 きめに見積もられる傾向が見られた地点があった。 これ は, 将来気象データセットを作成する際, 降水量に対す るスケーリング変換特性によって，降水量の最大值が増 幅される影響を反映したものと考えられる.

温暖化に伴う気候変動によって, 洪水や干ばっをはじ
めとする極值現象の発生頻度の増加や強度の強大化は, 既に多数の論文で報告されている．洪水の発生頻度やそ の規模は，その社会的リスクの大きさから，水文シミュ レーションなどにより熱心に取り組まれている将来影響 予測の研究テーマの一つである. SS変換によるバイアス 補正は，簡便な温暖化実験を可能にし，多数の価值ある 成果を生み出してきたが，極值現象の解析には，長期間 のデータを用いることによる解析結果の安定化を過信せ ず，単年ごとのデータ特性についても確認を行なった上 で活用することが重要である.

謝辞 : 本研究は, 環境省環境研究総合推進費(S-10)によ り実施された. 入力気象データとして使用したPiani手法 のMIROC-ESM-CHEM気象データは, ISI-MIPにより作 成・配布されたものを使用した．改稿にあたり，3名の 匿名査読者から有益な意見をいただいた。

\section{参考文献}

1) Hagemann, S., Chen, C., Haerter, J.O., Heinke, J., Gerten, D. and Piani, C.: Impact of a statistical bias correction on the projected hydrological changes obtained from three GCMs and two hydrology models, J. Hydrometeorol., Vol.12, pp.556-578, 2011.

2) Moss, R.H., Edmonds, J.A., Hibbard, K.A., Manning, M.R., Rose, S.K., van Vuuren, D.P., Carter, T.R., Emori, S., Kainuma, M., Kram, T., Meehl, G.A., Mitchell, J.F.B., Nakicenovic, N., Riahi, K., Smith, S.J., Stouffer, R.J., Thomson, A.M., Weyant, J.P. and Wilbanks, T.J.: The next generation of scenarios for climate change research and assessment, Nature, Vol. 463, pp. 747-756, 2010.

3) Hanasaki, N., Kanae, S., Oki, T., Masuda, K., Motoya, K., Shirakawa, N., Shen, Y. and Tanaka, K.: An integrated model for the assessment of global water resources - Part 1: Model description and input meteorological forcing, Hydrol. Earth Syst. Sci., Vol.12, pp.1007-1025, 2008.

4) Weedon, G.P., Gomes, S., Viterbo, P., Shuttleworth, W.J., Blyth, E., Österle, H., Adam, J.C., Bellouin, N., Boucher, O. and Best, M.: Creation of the WATCH forcing data and its use to assess global and regional reference crop evaporation over land during the twentieth century, J. Hydrometeorol., Vol.12, pp.823-848, 2011

5) Piani, C., Haerter, J.O. and Coppola, E.: Statistical bias correction for daily precipitation in regional climate models over Europe, Theor. Appl. Climatol., Vol.99, pp.187-192, 2010.

6) Piani, C., Weedon, G.P., Best, M., Gomes, S.M., Viterbo, P., Hagemann, S. and Haerter, J.O.: Statistical bias correction of global simulated daily precipitation and temperature for the application of hydrological models, J. Hydrol., Vol.395, pp.199-215, 2010.

7) The Intersectoral Impact Model Intercomparison Project (ISI-MIP): Project design and simulation protocol, Version 1.3, 2012.

(2012. 9. 30受付) 